

\title{
Greenhouse propagation of the endangered hemiparasite Schwalbea americana (American chaffseed): experimentation and botanical studies
}

\author{
Danny J Gustafson, Steven E Woodyard Jr, Joaquin Marquez, W Duncan Rhoad V, \\ Jeff S Glitzenstein, and Joel M Gramling
}

ABSTRACT

American chaffseed (Schwalbea americana L. [Scrophulariaceae]) is a federally endangered, hemiparasitic species that primarily occurs in fire-maintained pinelands in the Atlantic and Gulf coastal plains of the US. Efforts to propagate S. americana for reintroduction into the wild have been met with mixed results. Discrepancies in our understanding of host requirements, soil ecology, and growing conditions need to be resolved in order to develop a successful ex situ propagation program. We conducted a series of greenhouse experiments to address the impact that growth media, soil microbes, mycorrhizal associations, and autoparasitism may have on successful propagation of seedlings. We also tested the effectiveness of storing bareroot plants at $4{ }^{\circ} \mathrm{C}$ $\left(39^{\circ} \mathrm{F}\right)$ relative to plants overwintering outside or being maintained in the greenhouse. We confirmed that cold-moist stratification is necessary to achieve the high germination rates needed for ex situ propagation. Soil microbes and growth media affected $S$. americana survivorship. We successfully grew plants in the absence of host plants by supplementing nursery media with organic hydrolized fish fertilizer. We did not observe S. americana forming mycorrhizal associations or parasitizing its own roots (no autoparasitism). Finally, we demonstrated that 1 -y-old bareroot plants stored for 3 mo at $4{ }^{\circ} \mathrm{C}$ exhibited survival rates that rivaled plants that overwinter outdoors or in the greenhouse.

Gustafson DJ, Woodyard SE Jr, Marquez J, Rhoad WD V, Glitzenstein JS, Gramling JM. 2017. Greenhouse propagation of the endangered hemiparasite Schwalbea americana (American chaffseed): experimentation and botanical studies. Native Plants Journal 18(1):50-59.

\section{KEY WORDS}

This open access article is distributed under the terms of the CCBYNCND license (http:// creativecommons.org/licenses/ byncnd/3.0) and is freely available online at: http://npj.uwpress.org.

ex situ propagation, native soil microbes, growth media, arbuscular mycorrhizal fungi, intraspecific parasitism, endangered species, Scrophulariaceae

NOMENCLATURE

USDA NRCS (2015) 
$\mathrm{T}$ The Endangered Species Act 1) guides the process for determining whether a candidate species becomes listed as threatened or endangered based solely on scientific data; 2) provides legal protection for listed species; and 3) requires a detailed recovery plan with specific criteria for considering the species sufficiently recovered (U.S. Code 2015). A recovery plan for endangered and threatened species seeks to increase the number of populations and to promote long-term population viability through best management practices (Foin and others 1998; Taylor and others 2005). The US Fish and Wildlife Service and the National Marine Fisheries Service continue to update their procedures for recovery planning (NMFS and USFWS 2010); however, these recovery plans often highlight the gaps in our understanding of the basic biology and ecology of the species of interest. In this article, we document our basic and applied botanical research on the endangered hemiparasite Schwalbea americana L. (Scrophulariaceae; Amer- ican chaffseed) to facilitate this plant's recovery through improved ex situ propagation.

Schwalbea americana is a federally endangered, hemiparasitic, perennial herbaceous species that occurs historically in fire-dependent coastal plain ecosystems from Massachusetts to Louisiana (USFWS 1992, 1995, 2008). As a root hemiparasite, it can parasitize the roots of other plant species, although doing so is not a requirement for growth and survival (Helton and others 2000). The current distribution of S. americana consists of populations in Louisiana (1), Alabama (1), Florida (1), Georgia (4), South Carolina (33), North Carolina (11), and New Jersey (2), with $60 \%$ of the sites occurring on private or public lands with some level of protection by the landowner (USFWS 2008). Fire is a natural disturbance in the longleaf pine ecosystem and has been shown to promote $S$. americana sexual reproduction and genetic diversity (Kirkman and others 1998; Norden and Kirkman 2004). The decline of S. americana pop-

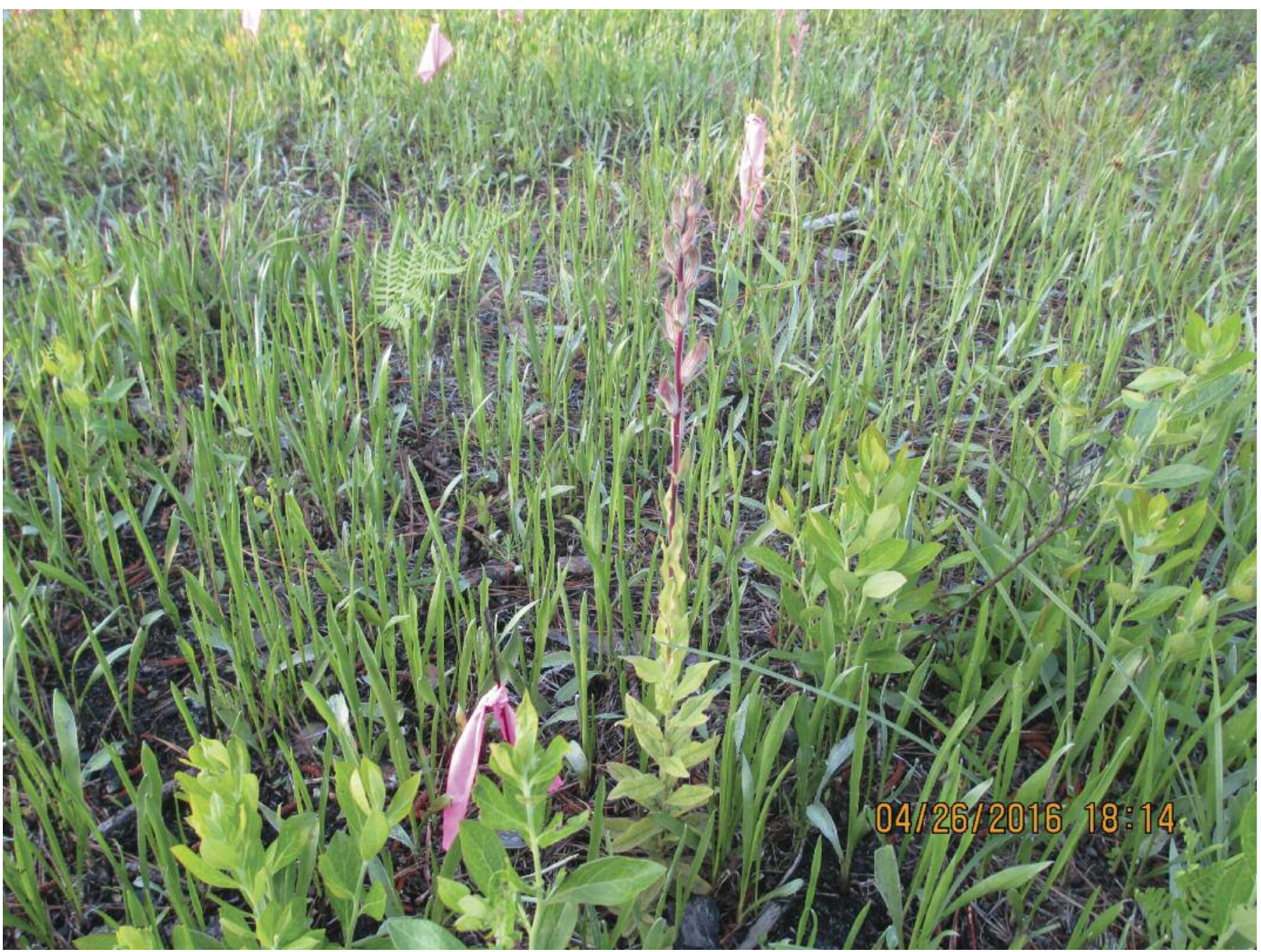

Schwalbea americana pictured during spring 2016 after a fire at the Woods Bay HP restoration site. Displayed is one of the plants that we grew and outplanted. In addition to the large flowering and non-flowering S. americana plants, note the native host plant-Pityopsis graminifolia (Michx.) Nutt. (Asteraceae; narrowleaf silkgrass)—surrounding the chaffseed. Photo by Jeff Glitzenstein 
ulations has been attributed to fire suppression and to the loss of open longleaf pine savanna habitat (Peters 1995). Schwalbea americana has a wide range of potential host species, with $S$. americana seedling size influencing year-to-year survivorship regardless of host species (Musselman and Mann 1979; Helton and others 2000).

A review of recovery activities associated with S. americana identified the need to continue to expand greenhouse propagation for reintroduction within its historic range (USFWS 2008). Review of the published literature indicates variation in seed germination requirements, with some studies documenting no seed dormancy (Determann and others 1997; Kirkman and others 1998; Helton and others 2000) and others indicating coldmoist stratification is required to achieve high germination rates (Brumback 1989; Johnson 1995; Obee 1995; Obee and Cartica 1997). Although variation in seed dormancy can be adaptive (Simons and Johnston 2006), the most recent US Fish and Wildlife Service review of this endangered species recommends cold-moist stratification to promote high seed germination rates as the best management practice (USFWS 2008).

In the absence of a host plant, results are mixed when trying to grow S. americana with supplemental fertilization (Mann and Musselman 1981; Determann and others 1997; Obee and Cartica 1997; Helton and others 2000; Kelly 2006). A better understanding of the soil ecology of $S$. americana could facilitate improvements in both propagation and establishment. It is par- ticularly important to address how mycorrhizal fungi or autoparasitism might supplement plant nutritional needs. Arbuscular mycorrhizal fungi (AMF) may serve as an alternative nutrient strategy in the absence of a host plant, whereas other studies indicate that AMF associations enhance or suppress parasitism (Li and Guan 2008; Li and others 2012). Parasitic plants have presumably evolved means of identifying "self," because there would be little benefit to parasitizing one's own roots (Westwood and others 2010). Nonetheless, parasitic plants have been known to initiate haustoria formation in the absence of a host plant (autohaustoria), to parasitize other parasitic plant species (epiparasitize), and even to parasitize members of their own species or themselves (autoparasitize) (Yeo 1961; Ehleringer and Schulze 1985; Yoder 1997).

Determining the ecological soil dynamics required for successful root development may also support an alternative approach to $S$. americana plantings. Healthy bareroot plants produced from seeds could provide a cost-effective means for introducing propagated plants back into the wild. To establish a successful ex situ propagation program, we must determine if growth media and fertilizer augmentation promote $S$. americana growth without a host plant, and if there is a means of producing bareroot plants to efficiently provide source plants for restoration and conservation activities. The overall objective of our research is to provide a means of propagating plants of $S$. americana under greenhouse conditions from seeds that

\begin{tabular}{|c|c|c|c|c|c|}
\hline $\begin{array}{l}\text { Seed collection } \\
\quad 8 / 23 / 2013\end{array}$ & & & & & \\
\hline \multirow{5}{*}{$\begin{array}{l}\text { Longlands } \\
\text { ( } 42 \text { capsules) } \\
\text { and Scotswood ( } 21 \\
\text { capsules) plantations, } \\
\text { Williamsburg County, } \\
\text { SC. }\end{array}$} & \multirow{3}{*}{\begin{tabular}{|l|}
$\begin{array}{l}\text { Cold-moist stratification } \\
10 / 1 / 2013-11 / 1 / 2013\end{array}$ \\
Seeds from each \\
source population \\
were wrapped in \\
paper towels, \\
moistened with diH $_{2} \mathrm{O}$, \\
sealed in 1 gal \\
Ziplock plastic bags, \\
and stratified for $30 \mathrm{~d}$ \\
at $4{ }^{\circ} \mathrm{C}$. \\
\cline { 2 - 3 }
\end{tabular}} & \multicolumn{4}{|c|}{$\begin{array}{l}\text { Continue to grow S. americana plants for use in experiments and population } \\
\text { restoration activities (Glitzenstein and others 2016). }\end{array}$} \\
\hline & & \multirow{2}{*}{$\begin{array}{l}\text { Testing seed source, } \\
\text { growth media, and } \\
\text { addition of native soil } \\
\text { microbes on plant } \\
\text { germination and } \\
\text { establishment. }\end{array}$} & $\begin{array}{c}\text { Organic fertilizer } \\
\text { experiment } \\
4 / 4 / 2014-4 / 25 / 2014\end{array}$ & & \\
\hline & & & \multirow{2}{*}{$\begin{array}{l}\text { Testing plant growth } \\
\text { differences between } \\
2 \text { commercially } \\
\text { available organic fish } \\
\text { fertilizers. }\end{array}$} & $\begin{array}{c}\text { Mycorrhizal fungi and } \\
\text { autoparasitism } \\
10 / 13 / 2014\end{array}$ & \\
\hline & & & & $\begin{array}{l}\text { Assessing if } \\
\text { S. americana } \\
\text { forms mycorrhizal } \\
\text { associations or } \\
\text { parasitizes S. } \\
\text { americana roots } \\
\text { (autoparasitism). }\end{array}$ & $\begin{array}{c}\text { Bareroot plant } \\
\text { experiment } \\
3 / 20 / 2015-6 / 10 / 2015\end{array}$ \\
\hline & & & & & $\begin{array}{l}\text { Testing relative } \\
\text { survivorship of } S \text {. } \\
\text { americana plants that } \\
\text { overwintered } \\
\text { outdoors, maintained } \\
\text { in the greenhouse, or } \\
\text { stored for } 3 \text { mo as } \\
\text { bareroot plant } \\
\text { material at } 4{ }^{\circ} \mathrm{C} \text {. }\end{array}$ \\
\hline
\end{tabular}

Figure 1. Timeline of the Schwalbea americana research and botanical observations conducted with a single cohort of seeds from 2 South Carolina source populations. Schwalbea americana is an endangered species, therefore any plants alive after an experiment were made available to restoration professionals. In addition, several hundred plants not used in experiments were also grown and made available to restoration professionals. Approximately 2000 S. americana plants were successfully germinated and grown ex situ during this 21-mo series of experiments. 
can then be planted back into established populations, can replace extirpated populations, or can create new populations within its historic range (Glitzenstein and others 2016).

Ex situ propagation procedures are needed so that plant enthusiasts, as well as nursery professionals, can successfully grow the endangered S. americana, thus providing plant material for reintroduction efforts (USFWS 2008). This research was conducted with a single cohort of seeds collected in 2013 from 2 South Carolina source populations, generating more than 2000 $S$. americana plants during this 2-y series of experiments. All living plants were made available to $S$. americana restoration professionals for outplanting (Figure 1). Five specific research questions addressed in this study contribute to ex situ propagation of the endangered hemiparasitic S. americana. 1) Do growth media and soil microbes from native $S$. americana locations affect seedling establishment and growth in the absence of a host plant? 2) Does S. americana form mycorrhizal associations? 3) Do we find evidence of $S$. americana parasitizing asitism)? 4) Can we create $S$. americana bareroot material by growing plants without host plants with supplemental organic fertilizer? 5) What is bareroot plant performance relative to plants overwintering outside or maintained under greenhouse conditions?

\section{MATERIALS AND METHODS}

Mature capsules of S. americana were collected on 23 August 2013 from Longlands Plantation (42 capsules) and Scotswood Plantation (20 capsules) in Williamsburg County, South Carolina. Individual capsules were collected from across the entire population, with one capsule per plant. Capsules were placed in paper envelopes and stored at $4^{\circ} \mathrm{C}\left(39^{\circ} \mathrm{F}\right)$. Seeds from each source population were extracted from the capsules and mixed thoroughly. We used source-specific bulk seed collections, Longlands and Scotswood, in this study. Seeds were cold-moist stratified for $30 \mathrm{~d}$ at $4{ }^{\circ} \mathrm{C}$ (USFWS 2008). Imbibed seeds were transferred to standard seed trays (5 per source population)

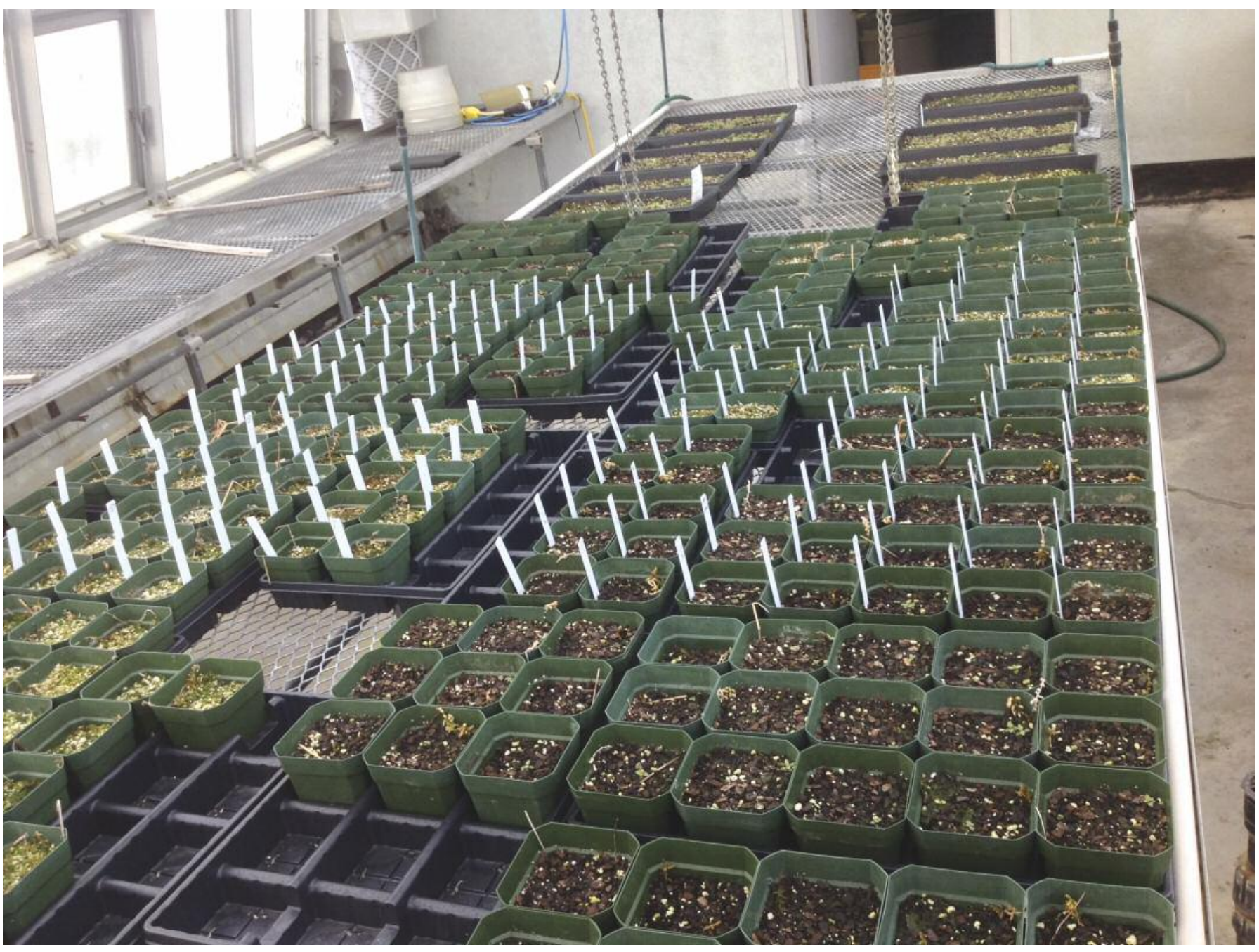

Greenhouse seed germination and establishment experiment, 2013-2014. Photo by Danny J Gustafson 
containing nursery growth media (50\% peat: $30 \%$ perlite: $20 \%$ vermiculite), covered with vermiculite to prevent desiccation, and watered by hand as needed. These plants were grown in the greenhouse for up to $21 \mathrm{mo}$ and used in a series of 4 experiments (Growth Media, Organic Fertilizer, Assessing Mycorrhizal Fungi and Autoparasitism, and Bareroot Plant). All living plants were made available for population restoration efforts of this endangered species. The greenhouse research was conducted in a $20 \times 30 \mathrm{~m}(65 \times 98 \mathrm{ft})$ rooftop greenhouse (circa 1971) with limited heating capability during the winter months (temperature $>10^{\circ} \mathrm{C}\left[50^{\circ} \mathrm{F}\right]$ ) and with cooling by way of roof ventilation, one exhaust fan, and an application of whitewash (Visor White, Becker Underwood, Ames, Iowa) that kept the internal temperature from exceeding $35^{\circ} \mathrm{C}\left(95^{\circ} \mathrm{F}\right)$ during summer months. Under these primitive greenhouse conditions, we successfully germinated and grew more than $2000 \mathrm{~S}$. americana plants during the 21-mo duration of this study. Plants were watered as needed, along with application of organic fish fertilizer monthly, except for plants in specific experiments.

\section{Growth Media Experiment}

We filled 150 square pots $(11.4 \mathrm{~cm}$ [4.5 in]) with either a commercially available growth media (2 parts Jungle Growth Professional Mix [Jungle Growth, Statham, Georgia]: 1 part vermiculite) or nursery growth media (50\% peat: $30 \%$ perlite: $20 \%$ vermiculite). We added 5 plants to each of 75 replicates for source population (Longlands, Scotswood) and growth media (Jungle Growth, Nursery). We mixed $150 \mathrm{~g}$ of soil collected under S. americana plants in the Francis Marion National Forest, South Carolina, with 41 (1 gal) sterile $\mathrm{diH}_{2} \mathrm{O}$ to make the native soil microbe slurry. Half of the pots from each source population were randomly selected to receive the $25-\mathrm{ml}$ soil microbe addition, whereas the remaining pots received a $25-\mathrm{ml} \mathrm{H}_{2} \mathrm{O}$ negative control. Pots were distributed randomly across the central growing bench on 1 November 2013 and were watered every 1 to $2 \mathrm{~d}$ as needed. Initially we supplied supplemental lighting (10 h light: $14 \mathrm{~h}$ dark) with full-spectrum solar greenhouse sodium vapor grow lamps, but we discontinued them after approximately $6 \mathrm{wk}$ (see Growth Media Experiment results). Organic fish fertilizer derived from seagoing fish emulsion (Alaska Fish Fertilizer, 5-1-1 Nitrogen Phosphorous Potassium (NPK), Lilly Miller Brands, Walnut Creek, California) was applied monthly following product application rates for indoor plants ( 1 tablespoon per gallon water) and plants were watered to saturation.

After 2.5 mo (15 January 2014), we recorded the number of plants per pot and individual plant height. The plants per pot data were cosine-transformed to achieve equal variance. Plants per pot and average plant height were analyzed using three-way ANOVA with 2 levels for population source, growth media, and microbes, using SAS Enterprise Guide (SAS Institute, Version 4.3, Cary, North Carolina).

\section{Organic Fertilizer Experiment}

To grow $S$. americana without a host plant, nursery professionals need to supplement plants with fertilizer. We compared 2 commercially available organic fish fertilizers, because organic fertilizers are less likely to burn plant roots and concentrated liquid organic fish fertilizer is widely available. On 4 April 2014, we transplanted 2 to 3 seedlings into 270 square $(11.4 \mathrm{~cm})$ pots filled with nursery growth media $(50 \%$ peat: $30 \%$ perlite; $20 \%$ vermiculite). We fertilized 90 pots with organic seagoing fish emulsion (Alaska Fish Fertilizer, 5-1-1 NPK) and 180 pots with organic hydrolyzed fish fertilizer (Neptune's Harvest Organic Fish Fertilizer, 2-4-1 NPK, Ocean Crest Seafood, Gloucester, Massachusetts). Pots were randomly located on greenhouse benches and were watered by hand as needed (1-2 d). Both fertilizers were diluted (1 tablespoon per gal water) and applied weekly.

\section{Mycorrhizal Fungi and Autoparasitism}

Pots with multiple, year-old plants growing under greenhouse conditions (Growth Media Experiment with soil microbe treatment) were selected for evaluating arbuscular mycorrhizal fungi associations and if S. americana parasitized itself or other $S$. americana individuals. We carefully removed 49 plants from pots, 2 to 4 plants per pot, thoroughly washed them, and examined for the presence of haustoria. We interpreted the presence of haustoria in pots with only S. americana plants as evidence of autoparasitism (Musselman and Mann 1979; Li and Guan 2008). Of these plants, 31 were used to assess the presence of arbuscular mycorrhizal fungi. Approximately $0.25 \mathrm{~g}$ fresh root tissue was cleared with potassium hydroxide (Fisher Scientific, Fair Lawn, New Jersey) and stained with trypan blue (Thermo Fisher Scientific, Waltham, Massachusetts) following the procedures of Koske and Gemma (1989). The percentage of root length with internal AMF infection (hyphae, vesicles, arbuscules, and spores) was determined using a compound microscope (McGonigle and others 1990).

\section{Bareroot Plant Experiment}

On 3 December 2014, we created S. americana bareroot plants by removing aboveground senesced biomass from $62 \mathrm{~S}$. americana plants, placed these plants in vermiculite moistened with sterile $\mathrm{diH}_{2} \mathrm{O}$, and stored them in the dark at $4{ }^{\circ} \mathrm{C}\left(39^{\circ} \mathrm{F}\right)$. The other 2 treatments consisted of 1 ) moving 60 pots outdoors and using supplemental watering and 2) maintaining 75 pots in the greenhouse where they were watered 3 times a week. Pots were watered to field capacity using the Southern Patio 2 Gallon Green Watering Can (Griffon Corporation, New York).

On 20 March 2015, 54 of the original 62 S. americana bareroot plants were healthy (firm, opaque or whitish color, with no visual evidence of root pathogens). Bareroot plants were planted into $11.4-\mathrm{cm}$ square pots containing nursery growth media, with a single plant in 24 pots and 2 plants in 15 pots. 


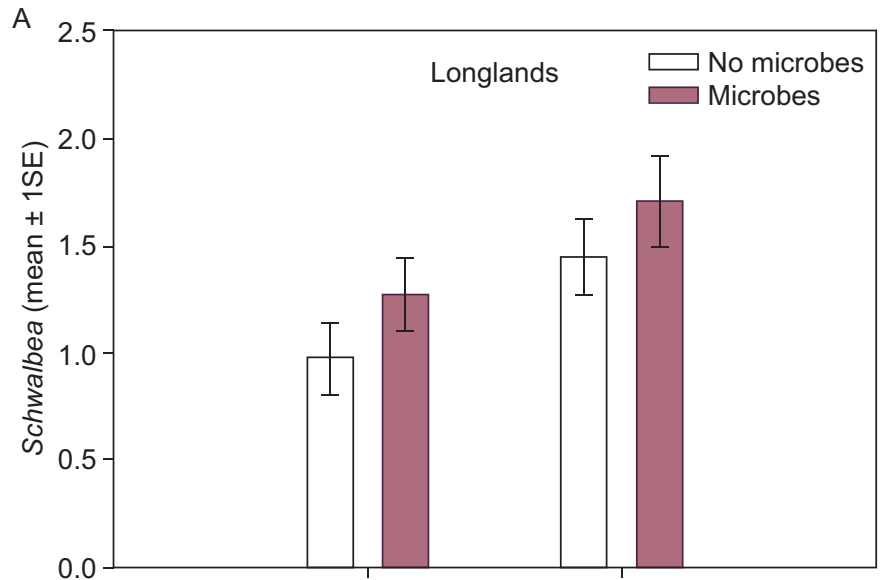

B

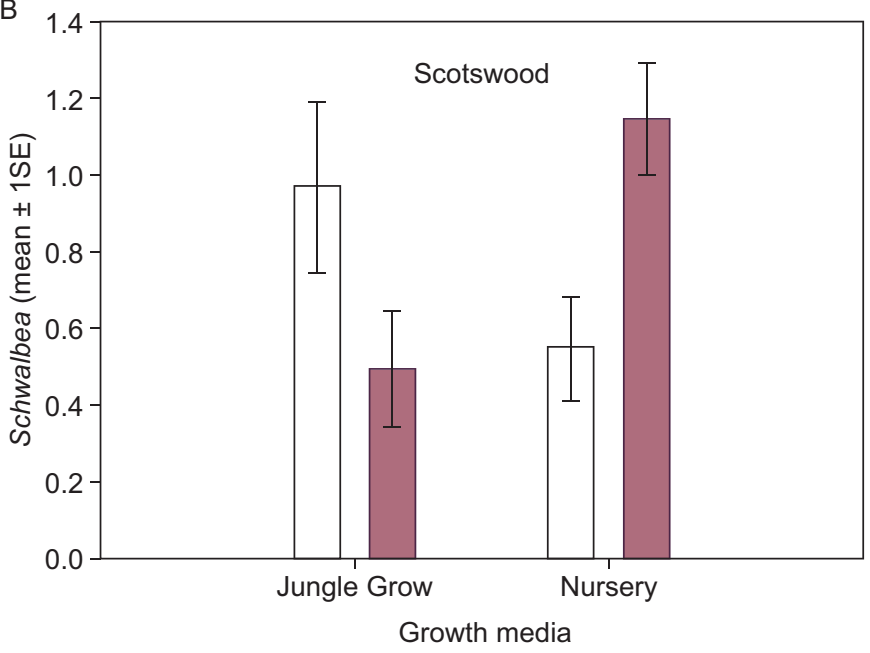

Figure 2. Average number of Schwalbea americana plants ( $\pm 1 \mathrm{SE}$ ) from 2 different source populations (Longlands and Scotswood Plantations, SC) growing in commercial (Jungle Grow) and nursery growth media, with (shaded lines) and without native soil microbes introduced. There was a significant three-way interaction

$\left(F_{1,287}=7.60, P<0.01\right)$ among population source, growth media, and microbe addition. Addition of microbes differentially affected Scotswood plant establishment based on the growth media. Error bars represent one standard error of the mean.

We used 2 planting densities because we observed that about half of our plants growing under greenhouse conditions without host plants seemed to grow better in the presence of a conspecific. The outdoor treatment pots were brought into the greenhouse on 20 March 2015. Plants for all 3 treatments (outdoors, greenhouse, and refrigerated) were maintained in the greenhouse until survivorship was evaluated on 10 June 2015. Chi-square tests (SAS Enterprise Guide) were used to determine differences in plant survival among the treatments.

\section{RESULTS}

\section{Growth Media Experiment}

A significant three-way interaction $\left(F_{1,287}=7.60, P<0.01\right)$

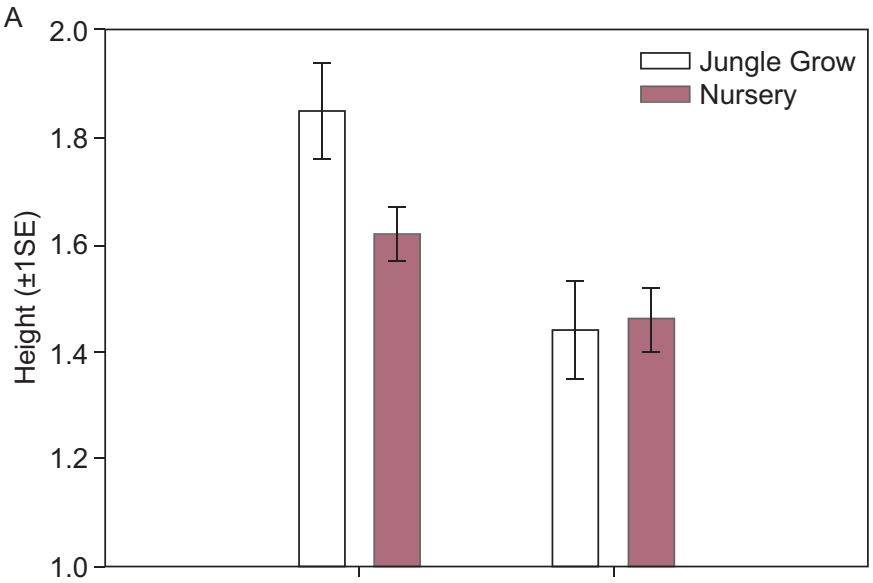

B

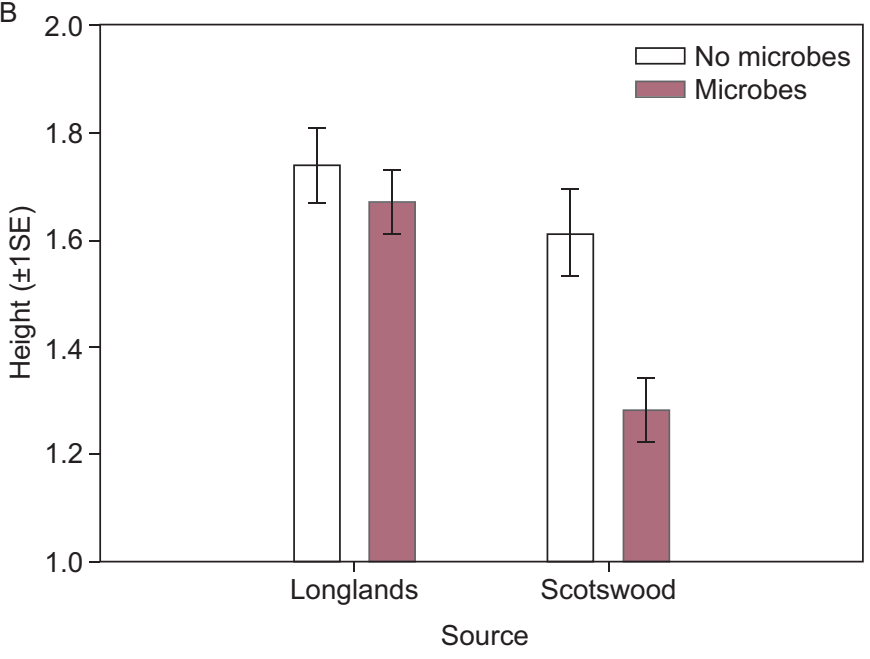

Figure 3. Significant Schwalbea americana population source by growth media $\left(F_{1,387}=3.83, P=0.05\right)$ (upper) and population source by microbes $\left(F_{1,387}=4.90, P=0.03\right)$ interactions (lower). Bars represent average height $(\mathrm{cm})$ and the error bars represent one standard error of the mean.

crobe addition. There were also significant population source $\left(F_{1,287}=18.50, P<0.01\right)$ and growth media $\left(F_{1,287}=6.76\right.$, $P<0.01$ ) main effects (Figure 2). In 3 of the 4 combinations of seed source and growth media, addition of native soil microbes improved S. americana establishment. The Scotswood plantation-sourced seed had higher establishment rates with the addition of native soil microbes in nursery growth media, but a reduction when soil microbes were added to the Jungle Grow media. It is possible that the reduced establishment rate of Scotswood plants in Jungle Grow media is the result of native soil microflora by commercial microflora interactions or is the result of the introduction of a native pathogen. We did not, however, identify the soil microflora in this study. There were significant population source by growth media $\left(F_{1,387}=3.83\right.$, $P=0.05)$ and population source by microbes $\left(F_{1,387}=4.90\right.$, $P=0.03)$ interactions when measuring average plant height (Figure 3). Longlands plants were taller than Scotswood plants regardless of the growth media. Scotswood plants without 
native soil microbes added were twice as tall as those plants with microbes.

An unexpected botanical observation from this experiment was the apparent light stress induced by the supplemental fullspectrum lighting (10 h light: $14 \mathrm{~h}$ dark). We observed individual plants with red and green sections on the same leaf. The green section of the $S$. americana leaves was shaded from the supplemental lighting, while the red areas received the supplemental lighting. When the supplemental lighting was discontinued, the red color was reduced in $24 \mathrm{~h}$, and the S. americana plants were completely green within $48 \mathrm{~h}$.

\section{Organic Fertilizer Experiment}

We ended the organic fertilizer experiment after $3 \mathrm{wk}$ because of a dramatic difference in mortality rates. Pots receiving the organic seagoing fish emulsion fertilizer (5-1-1 NPK) treatment suffered a $42.2 \%$ mortality rate (38 dead pots/90 pots) compared to a $4.4 \%$ mortality rate ( 8 dead pots $/ 180$ pots) with organic hydrolyzed fish fertilizer (2-4-1 NPK). Pots treated with the seagoing fish emulsion fertilizer had excessive algal growth whereas the hydrolyzed fish fertilizer pots had no detectable algal growth (Figure 4). It is unclear if the 10 times greater mortality was attributable to differences in nutrients provided (5-1-1 compared to 2-4-1 NPK), algal growth, or some combination. Weekly applications of the hydrolyzed fish fertilizer (2-4-1 NPK), however, did promote healthy growth of $S$. americana under greenhouse conditions without a host plant.

\section{Mycorrhizal Fungi and Autoparasitism}

In the 31 individual plants examined for the presence of arbuscular mycorrhizal fungi (AMF), only 3 plants had any evidence of fungal hyphae in the root system $(2 \%, 2 \%$, and $7 \%)$. The presence of haustoria on roots of plants growing in pots with other $S$. americana individuals would be indicative of autoparasitism (parasitizing its own species). We found no haustoria in the 49 plants examined for autoparasitism. Based on these botanical observations, S. americana does not appear to form mycorrhizal associations or to parasitize S. americana roots.

\section{Bareroot Plant Experiment}

Of the bareroot plants placed in the moistened vermiculite at $4{ }^{\circ} \mathrm{C}\left(39^{\circ} \mathrm{F}\right), 87 \%$ appeared viable and were planted into nursery growth media $(n=54)$. There was a significant difference in survival among the 3 treatments (outdoor, greenhouse, and bareroot; $\left.\chi^{2}=28.8, \mathrm{df}=2, P<0.0001\right)$. Plants that overwintered outdoors had the lowest survivorship with $43 \%$ of the pots producing at least a single $S$. americana plant, compared to $67 \%$ of the pots maintained under greenhouse conditions and bareroot plants (54\% with a single plant; $67 \%$ with 2 plants per pot). A significant difference $\left(\chi^{2}=30.3, \mathrm{df}=3, P<0.0001\right)$
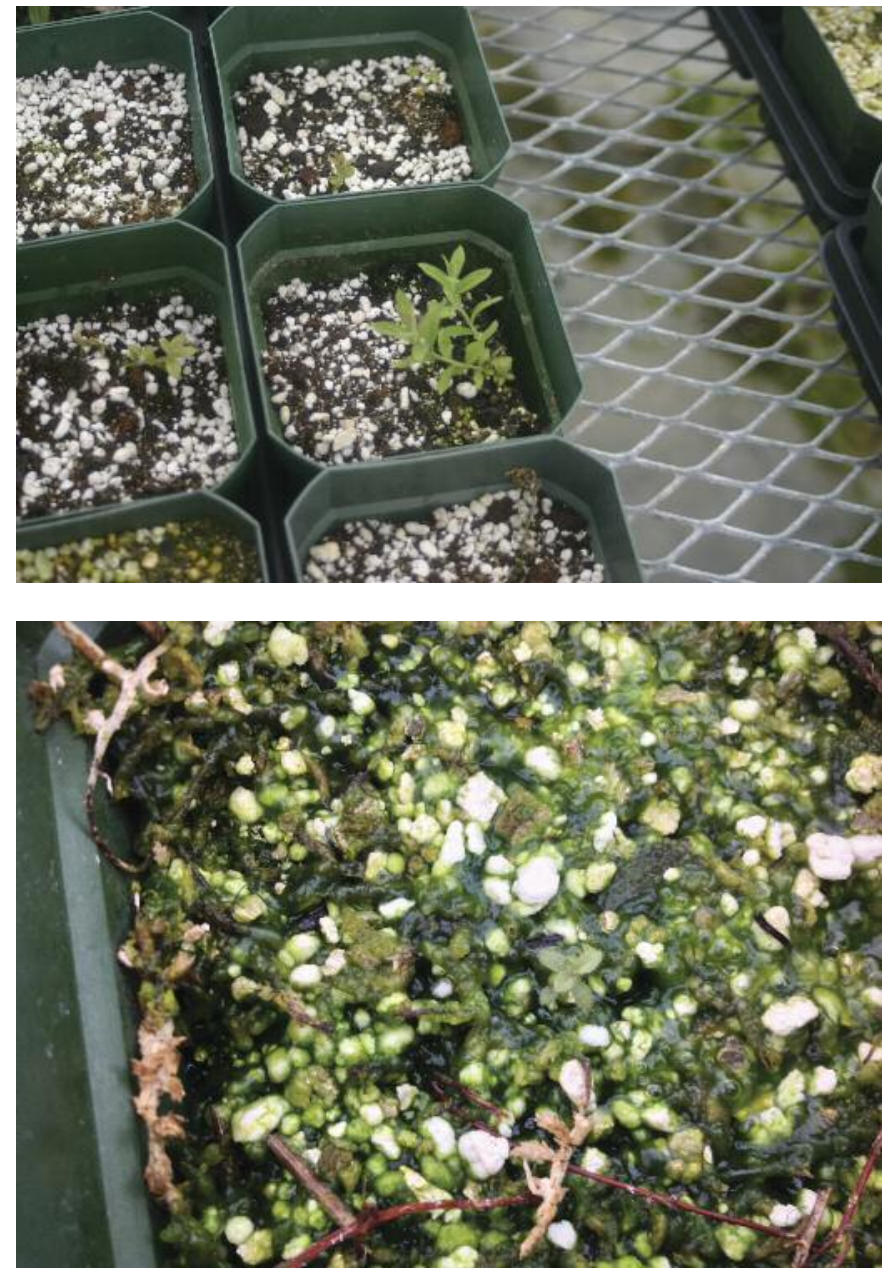

Figure 4. Schwalbea americana plants growing in nursery growth media in the organic fertilizer experiment. Hydrolyzed organic fish fertilizer (upper) and organic seagoing fish emulsion fish fertilizer (lower). Photos by Danny J Gustafson

occurred in the bareroot treatment between the single plant and the 2 plants per pot. It is possible that multiple plants in the same pot provide some benefit to the individual plants relative to single plants growing in isolation; however, we did not observe physiological integration by way of mycorrhizal networks or autoparasitism in this study. We were able to create $S$. americana bareroot material and to store it under cold-moist conditions for approximately $15 \mathrm{wk}$, with survival rates equal to or greater than plants maintained in the greenhouse or overwintering outdoors.

\section{DISCUSSION}

Recovery plans for endangered and threatened species include increasing the number of populations by locating previously known historical populations and restoring/creating populations within the species' historic range (NMFS and USFWS 2010). Ex situ propagation of endangered and threatened 
species can provide plants to be used for restoring or creating new populations rather than attempting to establish populations on-site from seeds. This finding may be especially important when working with hemiparasitic plant species, because restoration and conservation professionals will want to establish host plants as well. The overall goal of this research was to provide guidance for ex situ propagation of the endangered hemiparasitic S. americana in order to provide plants that can then be used in restoration and conservation plantings, as outlined in the S. americana recovery plan (USFWS 1995).

Significant population source, growth media, and soil microbe interactions were driven primarily by differences in the S. americana source populations. We expected plants to establish and to grow better in Jungle Grow commercial growth media because it more closely resembled soil. However, we experienced potting material breakdown and drainage issues within 2 mo with this commercial growth media. From a greenhouse management perspective, the standard nursery ( $50 \%$ peat: $30 \%$ perlite: $20 \%$ vermiculite) growth media maintained good drainage for the duration of this study. In addition, we were able to grow S. americana plants without a host plant for $21 \mathrm{mo}$ under primitive greenhouse conditions with weekly application of hydrolyzed fish fertilizer (2-4-1 NPK).

Schwalbea americana did not form mycorrhizal associations in this study, which was surprising because the addition of native soil microbes was generally associated with higher establishment rates. It is possible that native soil microflora collected from under S. americana plants in the Francis Marion National Forest, South Carolina, provided some benefit to S. americana growth under greenhouse conditions; however, plant source by soil microbial interactions are beyond the scope of this study. Furthermore, S. americana plants did not parasitize their own roots or those of other S. americana plants growing in the same pot. These results were surprising because we often observed better plant growth when grown with other $S$. americana plants compared to one plant per pot. With no mycorrhizal requirements or the potential of autoparasitism, ex situ propagation of more than one plant per pot could increase the number of plants grown without having to increase the number of pots.

Schwalbea americana bareroot material was created from the plants growing in the greenhouse and stored at $4{ }^{\circ} \mathrm{C}\left(39^{\circ} \mathrm{F}\right)$ in moist vermiculite for approximately $3 \mathrm{mo}$. These plants performed as well or better than plants that overwintered outdoors or were maintained in the greenhouse. This approach to $S$. americana propagation is novel and previously undocumented in the scientific literature. The one shelf of storage space in a refrigerator for these bareroots was considerably less than the bench space for the greenhouse-maintained plants, and not all facilities have space available for overwintering potted plants outdoors. In addition, restoration professionals can outplant a mature S. americana root system directly onto host plants in more flexibility and success in establishing S. americana in the field.

In conclusion, this study addressed several gaps in our understanding of the biology of the endangered hemiparasitic $S$. americana. We confirmed that cold-moist stratification is needed to have good (>90\%) seed germination, which is an essential first step in any ex situ propagation program from seeds. Schwalbea americana plants were able to be grown from seeds in a greenhouse using fairly standard nursery growth media formulation and the addition of organic hydrolyzed fish fertilizer. Finally, we show that 1-y-old bareroot plants stored for $3 \mathrm{mo}$ at $4^{\circ} \mathrm{C}$ had survival rates that rivaled plants that overwinter outdoors or in the greenhouse. Bareroot plant material is used in the native plant nursery industry, and our results suggest bareroot plants are a viable option for this endangered species.

\section{ACKNOWLEDGMENTS}

We thank Stephen Love, an associate editor, and two reviewers for providing valuable comments to improve the manuscript. We thank Longlands and Scotswood Plantations for the $S$. americana seed and Victor Vankus for providing seed germination information. We thank Isabella Gustafson, Riley Hill, Parker Gustafson, and Gracie Hill for their assistance in the greenhouse. This research was made possible through the continued support of The Citadel Foundation and the Department of Biology. All S. americana plants generated during the course of this research were used to establish new populations or to augment existing populations.

\section{REFERENCES}

Brumback WE. 1989. Notes on propagation of rare New England species. Rhodora 91:154-162.

Determann R, Kirkman LK, Nourse H. 1997. Plant conservation by propagation: the cases of Macranthera and Schwalbea. Tipularia 12:2-12.

Ehleringer JR, Schulze ED. 1985. Mineral concentrations in an autoparasitic Phoradendra californicum growing on a parasitic Phoradendra californicum and its host, Cercidium floridum. American Journal of Botany 72:568-571.

Foin TC, Riley SPD, Pawley AL, Ayres DR, Carlsen TM, Hodum PJ, Switzer PV. 1998. Improving recovery planning for threatened and endangered species. Bioscience 48:177-184.

Glitzenstein JS, Gustafson DJ, Stowe JP, Streng DR, Bridgman DA, Fill JM, Ayers JT. 2016. Starting a new population of Schwalbea americana on a longleaf pine restoration site in South Carolina. Castanea 81:302-313.

Helton RC, Kirkman LK, Musselman LJ. 2000. Host preference of the federally endangered hemiparasite Schwalbea americana L. (Scrophulariaceae). Journal of the Torrey Botanical Society 127:300-306.

Johnson G. 1995. Schwalbea americana seed and pod measurements; germination and seedling growth; Francis Marion National Forest 1993 Collections. USDA Forest Service. 10 p. 
Kelly JF. 2006 Explanation in the biology and restoration of the endangered plant species, Schwalbea americana (American Chaffseed), in New Jersey [PhD dissertation]. New Brunswick (NJ): Rutgers State University of New Jersey. 206 p.

Kirkman LK, Drew MB, Edwards D. 1998. Effects of experimental fire regimes on the population dynamics of Schwalbea americana $\mathrm{L}$. Plant Ecology 137:115-137.

Koske RE, Gemma JN. 1989. A modified procedure for staining roots to detect VA mycorrhizas. Mycological Research 92:486-488.

Li AR, Guan KY. 2008. Arbuscular mycorrhizal fungi may serve as another nutrient strategy for some hemiparasitic species of Pedicularis (Orobanchaceae). Mycorrhiza 18:429-436.

Li AR, Smith AE, Smith FA, Guan KY. 2012. Inoculation with arbuscular mycorrhizal fungi suppresses initiation of haustoria in the root hemiparasite Pedicularis tricolor. Annals of Botany 109:1075-1080.

Mann WF Jr, Musselman LJ. 1981. Autotrophic growth of southern root parasites. American Midland Naturalist 106:203-205.

McGonigle TP, Miller MH, Evans DG. 1990. A new method which gives an objective measure of colonization of roots by vesicular-arbuscular mycorrhizal fungi. New Phytologist 114:495-501.

Musselman, LJ, Mann WF Jr. 1979. Haustorial frequency of some root parasites in culture. New Phytologist 83:479-483.

[NMFS and USFWS] National Marine and Fisheries Service, U.S. Fish and Wildlife Service. 2010. Interim endangered and threatened species recovery planning guidance, Ver. 1.3. URL: https://www.fws .gov/endangered/esa-library/pdf/NMFS-FWS_Recovery_Planning_ Guidance.pdf (accessed 1 Dec 2015).

Norden AH, Kirkman LK. 2004. Factors controlling the fire-induced flowering response of the federally endangered Schwalbea americana L. (Scrophulariaceae). Journal of the Torrey Botanical Society 131:16-22.

Obee EM. 1995. Management and monitoring of Schwalbea americana at Whitesbog. Trenton (NJ): New Jersey Department of Environmental Protection and Energy, Division of Parks and Forestry, Office of Natural Lands Management. 24 p.

Obee EM, Cartica RJ. 1997. Propagation and reintroduction of the endangered hemiparasite Schwalbea americana (Scrophulariaceae). Rhodora 99:134-147.

Peters D. 1995. American chaffseed recovery plan. Hadley (MA): U.S. Fish and Wildlife Services, Region 5. URL: https://projects .ncsu.edu/cals/plantbiology/ncsc/rare/Recovery_Schwalbea.pdf (accessed 1 Dec 2015).

Simons AM, Johnston MO. 2006. Environmental and genetic sources of diversification in the timing of seed germination: implications for evolution of bet hedging. Evolution 60:2280-2292.

Taylor MFJ, Suckling KF, Rachlinski JJ. 2005. The effectiveness of the Endangered Species Act: a quantitative analysis. Bioscience 55:360367.

[U.S. Code] United States Code. 2015. Title 16: Conservation, Chapter 35, U.S.C. section 1531.

[USDA NRCS] USDA Natural Resources Conservation Services. 2015. The PLANTS database. URL: http://plants.usda.gov (accessed 14 Oct 2015). Greensboro (NC): National Plant Data Team.

[USFWS] U.S. Fish and Wildlife Service. 1992. Endangered and threatened wildlife and plants: endangered status of Schwalbea americana (American chaffseed). Federal Register 57:44703-44708.

[USFWS] U.S. Fish and Wildlife Service. 1995. American chaffseed (Schwalbea americana) recovery plan. Hadley (MA): U.S. Depart- ment of the Interior, U.S. Fish and Wildlife Service. $38 p+$ appendices.

[USFWS] U.S. Fish and Wildlife Service. 2008. American chaffseed (Schwalbea americana) 5 year review: summary and evaluation. Pleasantville (NJ): U.S. Fish and Wildlife Service. 31 p.

Westwood JH, Yoder JI, Timko MP, dePamphilis CW. 2010. The evolution of parasitism in plants. Trends in Plant Science 15:227-235.

Yeo PF. 1961. Germination, seedlings, and the formation of haustoria in Euphrasia. Watsonia 5:11-22.

Yoder Jl. 1997. A species-specific recognition system directs haustorium development in the parasitic plant Triphysaria (Scrophulariaceae). Planta 202:407-413.

\section{AUTHOR INFORMATION}

\section{Danny J Gustafson}

Professor of Plant Molecular Ecology

Certified Senior Ecologist (ESA)

danny.gustafson@citadel.edu

Steven E Woodyard Jr

Undergraduate Researcher

swoodyar@gmail.com

Joaquin Marquez

Graduate Researcher

marquez_36@msn.com

W Duncan Rhoad V

Undergraduate Researcher

wrhoad@citadel.edu

Department of Biology

The Citadel

Charleston, SC 29409

Jeff S Glitzenstein

Research Associate and Beadel Fellow

Tall Timbers Research Station

13093 Henry Beadel Drive

Tallahassee, FL 32312

jeffglitz@aol.com

Joel M Gramling

Associate Professor of Plant Community Ecology

Curator of The Citadel Herbarium (CITA)

Department of Biology

The Citadel

Charleston, SC 29409

joel.gramling@citadel.edu 


\section{KASTE SEED}

Growers and Marketers of Native Grass and Wildflower Seed

ength We are your primary wholesale source for northern grown:

Big Bluestem | Blue Grama | Canada Milkvetch | Canada Wildrye | Indiangrass

Little Bluestem | Prairie Cordgrass | Purple Prairie Clover | Sideoats Grama

Switchgrass | Virginia Wildrye | White Prairie Clover

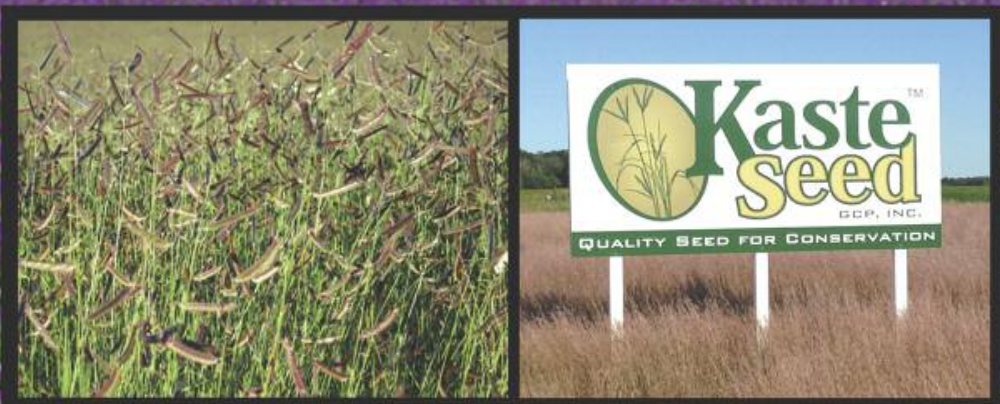

info@kasteseed.com | 218-945-6738 | fax 218-945-6303 | 11779 410th Street SE, Fertile, MN 56540 S

Kaste Seed-Growing Native Seeds Since 1983

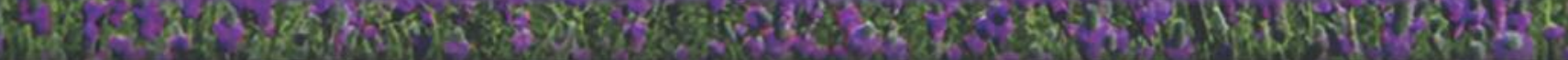

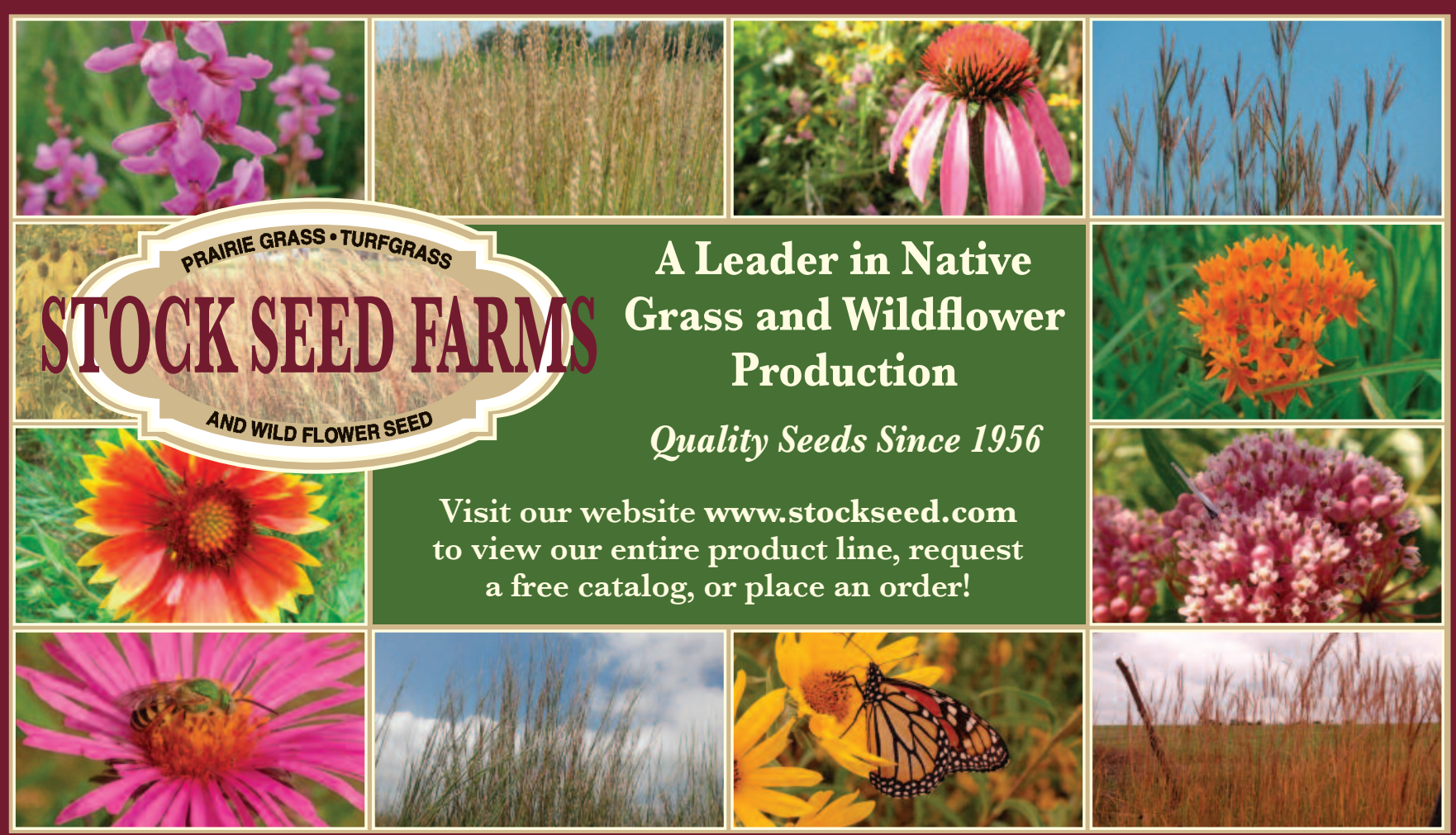

Email: prairie@stockseed.com • Phone: 800-759-1520 28008 Mill Road Murdock, NE 68407 


\section{Prairie Restorations, Inc. $y_{1}$}

Restoring Native Plant Communities Since 1977

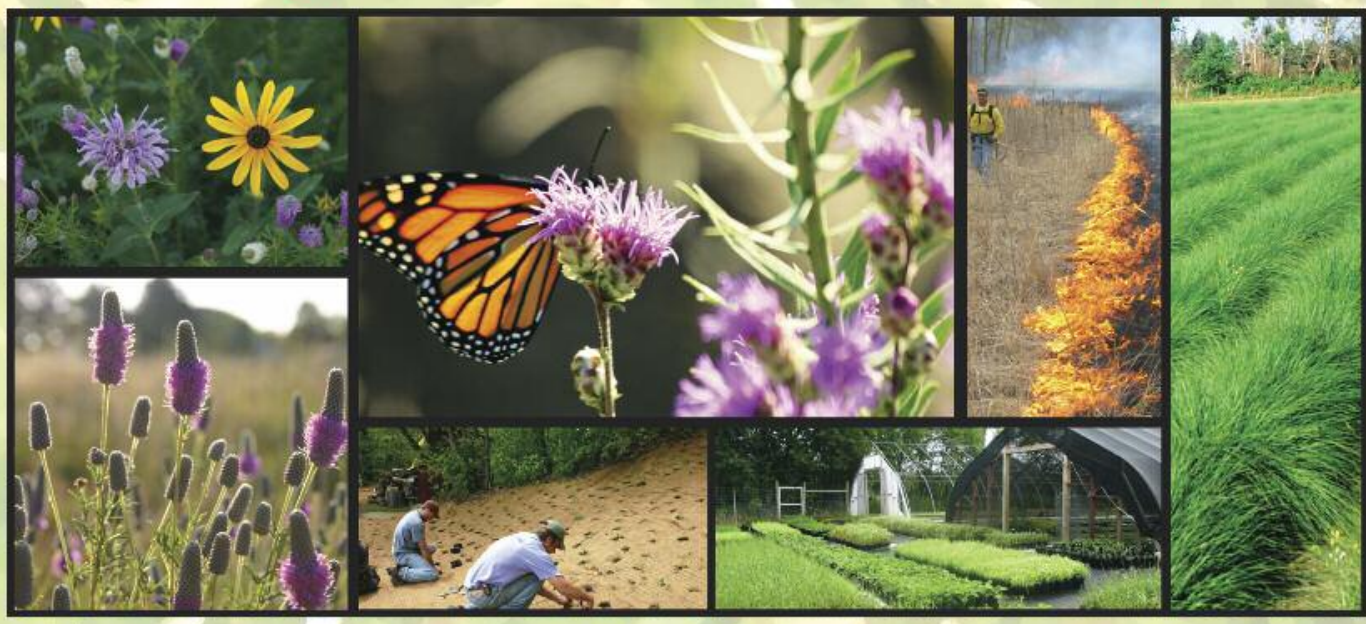

Prairie

Restorations, Inc.

31646 128th Street

Princeton, MN 55371

800-837-5986

www.prairieresto.com
Products:

Local Genotype Species Seed, Seed Mixes Plants, Trees, Shrubs Native Sod Flats
Services:

Landscape Design, Installation Technical Design Consulting Invasive Species Control Prescribed Burning

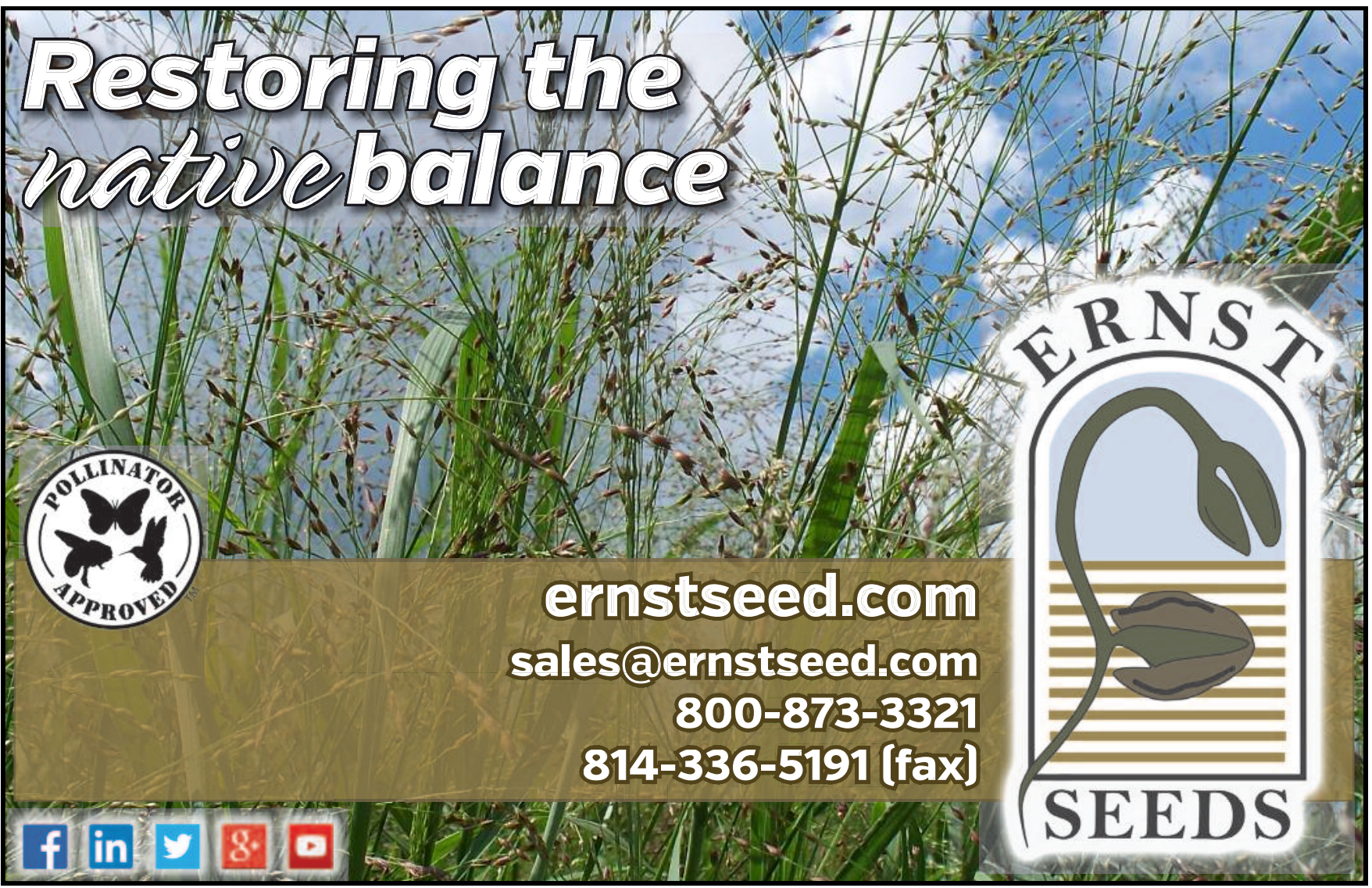

